\title{
Pengaruh Kepemimpinan Kepala Madrasah dan Disiplin Guru terhadap Profesionalitas Guru di Madrasah Tsanawiyah Negeri Kota Jambi
}

\author{
Ermailis, Raudhoh dan Risnita \\ Pascasarjana Universitas Islam Negeri Sulthan Thaha Saifuddin Jambi \\ E-mail: ermailis@gmail.com
}

\begin{abstract}
The influence of Madrasah principals' leadership and teacher discipline on the professionalism of teachers in the Public Islamic Junior High School or Madrasah Tsanawiyah Negeri in Jambi City has been carried out in this research using a quantitative approach. This study aims to analyze the influence of the principal's leadership and teacher discipline on the professionalism of teachers and the influence of the combination of both. Data was collected using a survey method with 63 respondents who were distributed to Sijenjeng Madrasah as many as 24 people, while in Talang Bakung Madrasah there were 39 people. Based on the results of this study, it is found that the better the headmaster's leadership accompanied by the discipline of a teacher will affect the better formation of teacher professionalism with value of the influence of the headmaster's leadership (83.72\%), teacher discipline (22.15\%), and combination of leadership of the madrasah-discipline teacher $(17.2 \%)$.
\end{abstract}

Keywords: Leadership of Principals; Teacher Professionalism: MTsN; Jambi City.

\begin{abstract}
Abstrak: Pengaruh kepemimpinan kepala sekolah Madrasah dan disiplin guru terhadap profesionalitas guru di Madrasah Thasanawiyah Negeri kota Jambi telah dilakukan menggunakan pendekatan kuantitatif. Penelitian ini bertujuan untuk menganalisis pengaruh kepemimpinan kepala madrasah dan disiplin guru terhadap profesionalitas guru di MTs Negeri Kota Jambi. Selain itu, pengaruh kombinasi kepemimpinan kepala madrasah-disiplin guru terhadap profesionalitas guru. Perolehan data dilakukan menggunakan metode survei dengan responden sebanyak 63 orang yang terdistribusi pada MTsN Sijenjeng Kota Jambi sebanyak 24 orang, sedangkan pada MTsN Talang Bakung sebanyak 39 orang. Berdasarkan Hasil penelitian ini menginformasikan bahwa semakin baik Kepemimpinan kepala madrasah yang disertai disiplin seorang guru maka akan berpengaruh terhadap terbentuknya profesionalitas guru yang semakin baik pula dengan nilai pengaruh kepemimpinan kepala madrasah $(83,72 \%)$, disiplin guru $(22,15 \%)$, dan kombinasi kepemimpinan kepala madrasah-disiplin guru $(17,2 \%)$.

Kata-kata kunci: Kepemimpinan Kepala Madrasah; Profesionalitas Guru; MTsN; Kota Jambi.
\end{abstract}

\section{Pendahuluan}

Mutu pendidikan menjadi inti dari jalannya sistem pendidikan di seluruh dunia, karena operasional berbasis mutu dapat memberikan hasil yang baik. Menurut Dedi Mulyasana, pendidikan bermutu lahir dari sistem perencaan yang baik (good planning System) dengan materi dan tata kelola yang baik (good govemence system) dan disampaikan oleh guru yang baik (good teachers) dengan komponen 
pendidikan yang bermutuํ. Dengan demikian, mutu pendidikan harus diiringi dengan langkah-langkah yang matang dan didukung oleh tenaga pengajar yang profesional.

Kemampuan atau kompetensi profesional guru adalah sejumlah kompetensi yang berhubungan dengan profesi yang menuntut berbagai keahlian di bidang pendidikan atau keguruan. Kompetensi profesional merupakan kemampuan dasar guru dalam pengetahuan tentang belajar dan tingkah laku manusia, sikap yang tepat tentang lingkungan proses pembelajaran dan mempunyai keterampilan dalam teknik mengajar ${ }^{2}$. Guru profesional adalah guru yang mampu mengelola dirinya sendiri dalam melaksanakan tugas sehari-hari. Menurut Martinis yamin profesi guru adalah suatu pekerjaan yang membutuhkan pengetahuan, keterampilan, kemampuan, keahlian dan ketelatenan untuk menciptakan anak didik yang memiliki prilaku yang diharapkan. Maksudnya seseorang akan bekerja profesional bilamana memiliki kemampuan tinggi dan kesungguhan hati untuk mengerjakan dengan sebaik-baiknya. Seorang guru dapat dikatakan profesional bila memiliki kemampuan tinggi (high level of abstract) dan motovasi kerja tinggi (high level of commitment).

Kemampuan profesional guru adalah kemampuan dalam melaksanakan tugas yang dibekali dengan kompetensi (kamampuan dasar) yang harus dimiliki oleh setiap guru antara lain: 1) penguasaan kurikulum. 2) penguasaan materi pelajaran, 3) penguasaan metode dan teknik mengajar, 4) komitmen terhadap tugas, 5) disiplin dalam arti luas. Disiplin guru berhubungan erat dengan kepatuhan dalam menerapkan peraturan sekolah. Sikap disiplin akan mendorong seorang guru untuk bekerja sesuai dengan ketentuan dan prosedur yang berlaku. Seorang guru yang disiplin akan melaksanakan tugasnya dengan sungguh-sungguh dan penuh tanggung jawab. Disiplin kerja yang tinggi akan menghasilkan kinerja yang baik. Kemampuan profesi adalah salah satu unsur penunjang bagi guru dalam mewujudkan prestasi kerja. Keberhasilan pendidikan di sekolah sangat ditentukan oleh keberhasilan kepala madrasah dalam mengelola tenaga kependidikan yang tersedia di madrasah. Kepala madrasah merupakan salah satu komponen pendidikan yang berpengaruh dalam meningkatkan kinerja guru. Kepala madrasah sebagai leader harus mampu memberikan petunjuk dan pengawasan, meningkatkan kemauan tenaga kependidikan, membuka komunikasi dua arah dan mendelegasikan tugas. ${ }^{3}$

Profesionalitas guru sangat berkaitan erat dengan tugas kepala madrasah untuk selalu melakukan komunikasi yang berkesinambungan, melalui jalinan kemitraan dengan seluruh guru disekolahnya. Perencanaan profesionalitas guru merupakan suatu proses dimana guru dan kepala madrasah bekerja sama merencanakan apa yang harus dikerjakan guru pada tahun mendatang, menentukan bagaimana kinerja harus diukur. Kebijakan kepala madrasah akan mempengaruhi mekanisme kerja madrasah dan berperan besar dalam

1 Dedi Mulyasana, Pendidikan Bermutu dan Berdaya Saing,(Bandung: PT Remaja Rosdakarya, 2012), hlm. 120.

2 Mukhtar dan Iskandar, Orientasi Baru Supervisi Pendidikan, (Jakarta: Gaung Persada, 2009), hlm. 127.

3 E. Mulyasa. Menjadi Kepala Sekolah Profesional, (Bandung: PT. Remaja Rosda Karya, 2009), hlm. 115 . 
meningkatkan disiplin guru. Kebijakan yang dapat mendorong peningkatan disiplin guru akan sangat berpengaruh terhadap peningkatan mutu madrasah. Sebaliknya, bila kebijakan tidak dapat mendorong peningkatan, maka kebijakan tersebut akan berdampak pada penurunan mutu madrasah. Maka disini, secara tidak langsung kebijakan sangat berperan dalam meningkatkan disiplin guru.

Kepala madrasah mempunyai tanggung jawab dan tugas untuk mengarahkan, mengontrol dan mengevaluasi serta mengkoordinasi berbagai pekerjaan yang diemban oleh guru, staf dan pegawai lainnya. Masalah kepemimpinan selalu memberikan kesan yang menarik, sebab suatu organisasi akan berhasil atau gagal sebagian ditentukan oleh kualitas kepemimpinan. Kunci utama keberhasilan aktivitas kerja sangat ditentukan oleh keprofesionalan guru, karena itu sikap profesional guru dapat meningkatkan kualitas madrasah sebagai suatu institusi. Mengingat pentingnya profesionalitas guru dalam aktivitas kerja maka diperlukan suatu usaha dan kebijakan yang tepat dalam mewujudkannya.

Madrasah Tsanawiyah Negeri Sijenjang dan Madrasah Tsanawiyah Talang Bakung yang menjadi lokasi penelitian ini juga memiliki permasalahan terhadap kepemimpinan kepala madrasah di dalam upaya meningkatkan disiplin guru. yaitu secara umum masih rendahnya budaya kedisiplinan guru, dari penjelasan di atas dapat diambil grand tour, diantaranya: Pertama, kepemimpinan kepala madrasah belum begitu optimal dalam menjalankan tugasnya dengan kedisiplinan kerja guru masih rendah, terlihat masih ada guru yang terlambat datang dan pulang terlebih awal. Kedua, pelaksanaan tata tertib yang belum optimal, yang belum dipatuhi dan dijalankan oleh sebagian guru. Ketiga, adanya kendala yang dihadapi kepala madrasah yaitu kepala madrasah kurang membangun kerja sama yang baik dengan sebagian guru. Keempat, upaya yang dilakukan kepala madrasah dalam meningkatkan disiplin guru diantaranya tidak melibatkan guru dalam menyusun program madrasah, bahwa ada beberapa program di madrasah yang tidak berjalan dengan baik. Kelima, guru mengajar tidak sesuai dengan latar belakang pendidikan yang diperoleh dimana ada beberapa guru agama mengajar pelajaran umum.

Penelitian yang dilakukan untuk menggali informasi menggunakan pendekatan kuantitatif dengan metode survei. Penelitian kuantitatif dikembangkan dengan mengunakan model matematis, teori-teori dan hipotesis. Analisis ini untuk menguji apakah terdapat pengaruh antara variabel kepemimpinan kepala madrasah $\left(\mathrm{X}_{1}\right)$ terhadap variabel profesionalitas guru $\left(\mathrm{X}_{3}\right)$, apakah terdapat pengaruh variabel disiplin guru $\left(\mathrm{X}_{2}\right)$ terhadap variabel profesionalitas guru $\left(\mathrm{X}_{3}\right)$,apakah terdapat pengaruh antara variabel kepemimpinan kepala madrasah $\left(\mathrm{X}_{1}\right)$ terhadap disiplin guru $\left(\mathrm{X}_{2}\right)$,dan apakah terdapat pengaruh variabel kepemimpinan kepala madrasah $\left(\mathrm{X}_{1}\right)$ terhadap variabel disiplin guru $\left(\mathrm{X}_{2}\right)$ secara bersama-sama terhadap variabel profesionalitas guru $\left(X_{3}\right)$ yang terdapat pada Gambar 1. Berdasarkan Gambar 1 bahwa $\mathrm{X}_{1}$ (Kepemimpinan Kepala Madrasah), $\mathrm{X}_{2}$ (Disiplin Guru) dan $\mathrm{X}_{3}$ (Profesionalitas guru). 


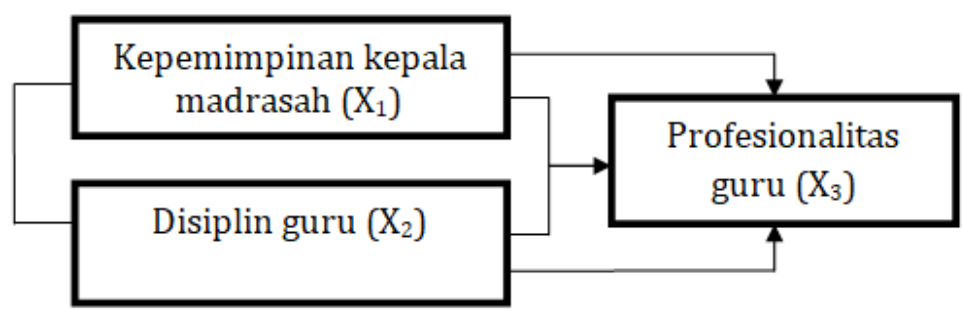

Gambar 1. Hubungan antara variabel bebas dan terikat pada penelitian ini.

Dalam penelitian ini, populasi adalah seluruh guru MTsN Sijenjang Kota Jambi yang berjumlah 28 orang dan MTs N Talang Bakung berjumlah 41 sehingga total 69 orang. Dalam penelitian ini teknik pengambilan sampel menggunakan teknik sampling jenuh yaitu teknik penentuan sampel bila semua populasi di gunakan sebagai sampel, pertimbangannya adalah populasi jumlahnya kecil yaitu kurang dari 100 orang. Jadi besarnya sampel dalam penelitian ini adalah semua guru Pegawai Negeri Sipil yaitu 63 orang4. Teknik pengumpulan data menggunakan cara dokumentasi dan angket.

Data yang digunakan dalam penelitian ini adalah data primer dan sekunder. Teknik analisa data dalam penelitian ini mengunakan teknis analisa data regresi sederhana dan regresi berganda dengan bantuan SPSS Windows versi 14 , sedangkan tahap pelaksanaan analisis meliputi analisis deskriptif, uji persyaratan analisis, dan uji hipotesis dengan penelitian selama 6 (enam) bulan dari April 2016-Februari 2017 di MTs Negeri Kota Jambi.

\section{Kepemimpinan Kepala Madrasah}

Secara umum kepemimpinan dapat dirumuskan sebagai kemampuan dan kesiapan yang dimiliki seseorang untuk dapat mempengaruhi, mendorong dan mengajak, menuntun, mengerakan, mengarahkan dan kalau perlu memaksa orang lain atau kelompok agar menerima pengaruh tersebut dan selanjutnya berbuat sesuatu yang dapat membantu tercapainya suatu tujuan yang ditetapkan ${ }^{5}$. Menurut Robert Kreitner dan Angelo Kinicki dalam bukunya "Organizational Behavior" bahwa "Leadership process whereby an individual influences others to achieve a common goal" yang artinya "proses kepemimpinan dimana seorang individu mempengaruhi orang untuk mencapai tujuan bersama". ${ }^{6}$ Kepemimpinan (leadership) merupakan pembahasan yang menarik karena kepemimpinan menjadi faktor yang sangat menentukan bagi keberhasilan suatu organisasi. Walaupun banyak faktor lain yang turut mempengaruhi dalam keberhasilan suatu organisasi, tetapi kepemimpinan menepati posisi yang sangat penting bagi jalannya sistem ataupun sub sistem yang terdapat dalam organisasi. Adapun faktor-faktor lain yang turut berpengaruh

4 Sukardi, Metodologi Penelitian Pendidikan Kompetensi dan Praktiknya,(Jakarta:Bumi Aksara,2013),hlm 55

5 Tim Dosen Administrasi Pendidikan Universitas Indonesia, Manajemen pendidikan (Bandung : Apabeta,200),hlm. 125

6 Robert Kreitner dan Angelo Kinicki, Organizational Behavior, (Amerika : Mc. Graw Hill Companies, 2007), hlm.. 509. 
terhadap pencapaian tujuan seperti sumber permodalan yang mencukupi, struktur organisasi yang akurat, dan adanya tenaga profesional yang cukup memadai7.

Sesuai dengan firman Allah dalam Al-Qur'an surat As-Sajdah ayat 24 yang berbunyi Artinya : " Dan Kami jadikan diantara mereka itu pemimpin-pemimpin yang memberi petunjuk dengan perintah Kami ketika mereka sabar dan adalah mereka meyakini ayat-ayat kami (QS As-Sajdah: 24), ${ }^{8}$

Ayat di atas mengamanatkan kepada seorang pemimpin untuk memberikan bimbingan dengan sabar kepada orang-orang yang dipimpin dengan berpedoman kepada petunjuk yang benar. Dengan kata lain dalam menjalankan kepemimpinan harus senantiasa berprilaku baik. Kepemimpinan juga diartikan sebagai suatu proses, kegiatan seseorang untuk mengerakan orang lain, untuk melaksanakan sesuatu dengan memimpin, membimbing, mempengaruhi orang lain, untuk melakukan sesuatu agar tercapai hasil yang diharapkan. ${ }^{9}$ Menurut Kim Marshall dalam bukunya yang berjudul Rethinking Teacher Supervision and Evaluation bahwa leadership experience for this kind of behavior yang artinya pengalaman kepemimpinan untuk jenis perilaku ${ }^{10}$.

Untuk menjadi seorang pemimpin tidaklah mudah, ada beberapa syarat yang harus dipenuhi antara lain :

a. Harus dapat menjadi seorang yang profesional.

b. Mampu menguasai unsur-unsur kepemimpinan.

c. Mampu mengatur urusan organisasinya dengan bijak dan adil.

d. Mampu memberikan motivasi pada bawahannya.

e. Memiliki dedikasi tinggi pada organisasi yang dipimpinnya ${ }^{11}$.

Faktor penentu keberhasilan seorang pemimpin diantaranya adalah "teknik kepemimpinan", yaitu bagaimana cara seorang pemimpin mampu menciptakan situasi sehingga menyebabkan orang yang dipimpinnya mempunyai kesadaran untuk melaksanakan apa yang dikehendaki oleh seorang pemimpin. Menurut Gary Yuky dalam bukunya yang berjudul Leadership in Organization bahwa Definitions of leadership reflect the assumption that if the leadership associated with the deliberate process of a person to suppress a strong influence on others yang artinya definisi kepemimpinan mencerminkan asumsi bahwa kepemimpinan berkaitan dengan proses yang disengaja dari seseorang untuk menekankan pengaruhnya yang kuat terhadap orang lain ${ }^{12}$. Sesuai dengan Qs. Shaad ayat 26 sebagai berikut: hlm. 38

7 Rohmat, Kepemimpinan Pendidikan Konsep dan Aplikasi (STAIN Press,Purwokerto,2010), hlm. 663.

8 Departemen agama, Al-qur'an dan terjemahannya,(Jakarta: Deartemen Agama RI,1989),

${ }^{9}$ Edy sutrisno, Manajemen Sumber daya Manusia, (Jakarta: Kencana prenada media Group, 2012), hlm. 213.

${ }^{10}$ Kim Marshall, Rethinking Teacher Supervision and Evaluation, (Amerika: John Wiley \& Sons, Inc, 2009), hlm.. 7.

11 Jamil Suprihatiningrum, Guru Profesional: Pedoman Kinerja, Kualifikasi, dan Kompetensi Guru, (Yogyakarta : Ar-Ruzz Media, 2013), h. 273.

12 Gary Yuky, Leadership in Organization, (New Jersey: Prentice Hall Inc., 2010), hlm.. 3. 
Artinya: Wahai Daud, Sesungguhnya Kami telah menjadikanmu khalifah di bumi, maka jalankanlah hukum diantara manusia dengan (hukum syariat) yang benar (yang diwahyukan kepadamu); dan janganlah Engkau menurut hawa nafsu, karena yang demikian itu akan menyesatkanmu dari jalan Allah. Sesungguhnya orangorang yang sesat dari jalan Allah, akan beroleh azab Yang berat pada hari hitungan amal, disebabkan mereka melupakan (jalan Allah) itu.

Menurut Robbin yang dikutip oleh Rohmat mengartikan kepemimpinan sebagai berikut: "leadership as ability to influence a group towar the achievement goal." Kepemimpinan merupakan kemampuan untuk mempengaruhi kelompok untuk mencapai tujuan.kepemimpinan lebih menekankan sejauh mana seorang pemimpin memiliki kemampuan untuk menjadikan para pengikut untuk dapat bersama-sama dalam mencapai tujuan yang ditentukan, sedangkan kemampuan seorang pemimpin tidak lepas dari kemampuan manajerial.

Menurut John R. Schermerhon, JR, dalam bukunya yang berjudul Introduction to Management bahwa "Leadership is the process of inspiring others to work hard to accomplish important tasks", yang artinya "kepemimpinan adalah proses menginspirasi orang lain untuk bekerja keras agar bisa menyelesaikan tugas-tugas penting"13. Menurut William B. Castetter dalam bukunya The Personnel Function in Educational Administration bahwa Leadership is a very personal process between two people, in which the one attempts to guide and motivate the other to make plans for achieving aims, yang artinya kepemimpinan adalah proses yang sangat pribadi antara dua orang, dimana salah satu upaya untuk membimbing dan memotivasi yang lain membuat rencana untuk mencapai tujuan dari sistem ${ }^{14}$. Untuk memperoleh kemantapan dalam merumuskan pengertian kepemimpinan ada baiknya dikemukakan terlebih dahulu beberapa pendapat tentang hal itu. ${ }^{15}$

1. Ordway Tead

"Leadership is the activity of influencing people to cooperate toward some goal which come to find desirable" (Kepemimpinan adalah aktivitas mempengaruhi orang-orang agar mau bekerjasama untuk mencapai beberapa tujuan yang mereka inginkan).

2. Reuter

"Leadership is an ability to persuade or direct men without use of the prestige or power of formal office or external circumstance". (Kepemimpinan adalah suatu kemampuan untuk mengajak atau mengarahkan orang-orang tanpa memakai perbawa atau kekuatan formal jabatan atau keadaan luar).

3. Franklyn S. Haiman

"Leadership is an effort on his put direct the behavior of others toward a particular end". (Kepemimpinan adalah suatu usaha untuk mengarahkan perilaku orang lain guna mencapai tujuan khusus).

4. Dubin

13 John R. Schermerhon, JR., Introduction to Management, (Hoboken: John. Wiley \& Sons (Asia) Pte Ltd, 2010), hlm.. 434.

14 William B. Castetter, The Personnel Function in Educational Administration, (New York Macmillan Publishing Co., Inc., tt), hlm.. 66.

15 Sutarto, Dasar-dasar Kepemimpinan Administrasi, (Yogyakarta : Gadjah Mada University Press, 1989), hlm.. 12-13. 
"Leadership is the exercise of authority and the making of decisions. (Kepemimpinan adalah menggunakan wewenang dan membuat keputusankeputusan).

Dalam kaitannya dengan ciri-ciri pemimpin, Gerungan menyatakan bahwa setiap pemimpin, sekurang-kurangnya memiliki tiga ciri,yaitu:(1) penglihatan sosial (2) berpikir abstrak, dan (3) keseimbangan emosi. Sedangkan menurut J. Slikboer, pemimpin hendaknya memiliki sifat-sifat : (1) dalam bidang intelektual, (2) berkaitan dengan watak, dan (3) berhubungan dengan tugasnya sebagai pemimpin. Ciri-ciri lain yang berbeda dikemukakan oleh Ruslan Abdulgani (1958) bahwa pemimpin harus mempunyai kelebihan dalam hal : (1) menggunakan pikiran; (2) rohani, dan (3) jasmani16.

Menurut Fred Luthans dan Jonathan P. Doh dalam bukunya International Management Culture, Strategy and Behavior, bahwa The specific types of leadership are : descrabe, examine, compare, review, discuss, yang artinya ada 4 tipe khusus kepemimpinan yaitu : menjelaskan, memeriksa, mereview, membandingkan dan membahas ${ }^{17}$. Dari beberapa pengertian di atas dapat disimpulkan pula bahwa kepemimpinan mengandung beberapa aspek kemampuan yang harus dimiliki oleh seorang pemimpin sebagai berikut:

a. Kemampuan untuk mempengaruhi orang lain dalam mencapai tujuan yang telah ditentukan.

b. Perilaku pemimpin merupakan teladan dan sumber inspirasi para pengikut.

c. Kemampuan dalam menggerakkan orang lain,modal,sumber daya intelektual yang ada pada organisasi pada arah yang benar.

\section{Profesionalitas Guru}

Profesi adalah kata serapan dari bahasa inggris yaitu "profesion" Yang berakar dari bahasa latin"profesus" yang berarti mengakui atau menyatakan mampu atau ahli dalam sutu bidang pekerjaan. Pekerjaan ini membutuhkan pendidikan akademik dan pelatihan yang panjang18. Menurut Vollmer dan L.Mills yang dikutip oleh Sudarman Danim dan Khairil, profesi adalah sebuah jabatan yang memerlukan intelektual khusus, yang diperoleh melalui kegiatan belajar dan pelatihan yang bertujuan untuk menguasai keterampilan atau keahlian dalam melayani orang lain, dengan memperoleh upah atau gaji dalam jumlah tertentu ${ }^{19}$ Profesi juga didefenisikan sebagai suatu pekerjaan yang didasarkan atas studi intelektual dan latihan yang khusus ${ }^{20}$. Dengan demikian profesi merupakan suatu jabatan atau pekerjaan yang menutut keahlian dan keterampilan dari pelakunya.

${ }^{16}$ Nanang Fattah, Landasan Manajemen Pendidikan, (Bandung : PT. Remaja Rosdakarya, 2009), hlm.. 89.

17 Fred Luthans dan Jonathan P. Doh, International Management Culture, Strategy and Behavior, (New York : Mc. Graw Hill : 2006), hlm.. 454.

18 Kennth Randrews,Towar Profesionalisme in Bussinnes Management horvard,(Busisnnes Review,Marc-April 1969), hlm.. 50-51

19 Sudarman Danim dan Khairil, Profesi Kependidikan,( Bandung: alfabeta, 2011), hlm.. 8

20 Pupuh Fathurrohman, Guru Profesional, (Bandung: PT Refika Aditama, 2012), hlm. 1 
Profesi memiliki ciri sebagai berikut: (1) merupakan pekerjaan yang memiliki fungsi sosial dituntut memiliki keahlian dan keterapilan tertentu, (2) mengunakan teori dan metode ilmiah dalam memperoleh keterampilan pekerjaan, (3) Batang tubuh ilmu suatu profesi didasarkan kepada suatu disiplin ilmu yang jelas, sistematis, (4) masa pendidikan lama, dan berkelanjutan dan dilakukan pada tingkat perguruan tinggi, (5) melayani klien dan masyarakat dengan sebaikbaiknya dan penuh tanggung jawab. Seorang yang profesional mempunyai prestasi yang tinggi dimata masyarakat, dan juga memperoleh imbalan yang layak. ${ }^{21}$ Dengan demikian dapat dikatakan bahwa suatu profesi pada dasarnya berpijak pada tiga pilar yaitu: (1) kemampuan atau kompetensi tingkat tinggi, (2) menerapkan layanan ahlinya, dan (3) pengakuan eksistensinya. ${ }^{22}$ Suryadi dalam Mulyasa menyatakan bahwa untuk menjadi profesional seorang guru dituntut untuk memiliki lima hal : (1) guru mempunyai komitmen pada siswa dan PBM, (2) guru menguasai secara mendalam mata pelajaran yang diajarkannya, (3) Guru bertanggung jawab memantau hasil belajar melalui berbagai cara evaluasi, (4) guru mampu berpikis sistematis, (5) guru seharusnya merupakan bagian dari masyarakat belajar dalam lingkungan profesinya ${ }^{23}$.

Profesionalitas berasal dari kata profesi yang berasal dari bahasa latin profess, profesio yang berarti pengakuan atau pernyataan di muka umum. Menurut Jasin, Anwar dalam Rahardjo Dawam profesionalitas dapat diartikan sebagai komitmen para anggota suatu profesi untuk meningkatkan kemampuan profesionalnya dan terus menerus mengembangkan strategi yang digunakan dalam melakukan pekerjaan sesuai dengan profesinya ${ }^{24}$. Menurut Kunandar bahwa profesionalitas berasal dari kata profesi yang artinya suatu bidang pekerjaan yang ingin atau akan ditekuni oleh seseorang. Profesi juga diartikan sebagai suatu jabatan atau pekerjaan tertentu yang mensyaratkan pengetahuan dan keterampilan diperoleh dari pendidikan akademis yang intensif. Jadi profesi adalah suatu pekerjaan atau jabatan yang menuntut keahlian tertentu ${ }^{25}$.

Menurut Muhaimin dalam buku pengembangan model KTSP menyatakan bahwa Visi sekolah/madrasah merupakan landasan utama dalam penyelenggaraan proses akademik. Dengan mendasarkan pada visi inilah kemudian sekolah/madrasah membutuhkan berbagai input untuk menyelenggarakan proses akademik. Input yang dibutuhkan sekolah/madrasah untuk mencapai proses akademik tersebut meliputi: peserta didik, guru dan tenaga akademik lain, pengawas sekolah, kurikulum, sumber daya dan kepemimpinan serta manajemen ${ }^{26}$.

Dalam buku Hamzah B Uno menurut Undang-undang Nomor 20 tahun 2003 Tentang Sistem Pendidikan Nasional pasal 39 ayat (2) menyembutkan

\footnotetext{
${ }^{21}$ Buchari, Alma Guru Profesional, (Bandung : alfabetha, 20090, hlm.. 133-137

22 Euis Karyawati dan Donni Juni Priansa, Kinerja dan profesionalisme kepala sekolah membangun Sekolah yang Bermutu, ( Bandung :Alfabeta, 2013), hlm..111-112.

${ }^{23}$ Mulyasa, Menjadi Guru Profesional, ( Bandung: PT Remaja Rosfa Karya, 2010), hlm.. 3-16

${ }^{24}$ Fachruddin Saudagar,Ali Idrus, Pengembangan profesionalitas guru,(Gaun Persada,2009),hlm. 96.

${ }^{25}$ Kunandar, Guru Profesional Implementasi Kurikulum Tingkat satuan Pendidikan (KTSP) dan Presiapan Menghadapi Sertifikasi Guru (Jakarta: Raja Grafindo Persada,2007),hlm. 45.

${ }^{26}$ Muhaimin, Sutiah dan Sugeng listyo prabowo, Pengembangan Model KTSP pada sekolah dan madrasah ( Jakarta: Raja Grafindo Persada, 2008) hlm. 14
} 
pendidik merupakan tenaga profesional yang bertugas merencanakan dan melaksanakan proses pembelajaran, menilai hasil pembelajaran, melakukan pembimbingan dan pelatihan serta melakukan penelitian dan pengabdian kepada masyarakat, terutama bagi pendidik pada perguruan tinggi 27.

Moh. Ali dalam buku Kunandar mengemukakan bahwa: Suatu pekerjaan profesional memerlukan persyaratan khusus, yakni (1) menuntut adanya keterampilan berdasarkan konsep dan teori ilmu pengetahuan yang mendalam; (2) menekankan pada suatu keahlian dalam bidang tertentu sesuai dengan bidang profesinya; (3) menuntut adanya tingkat pendidikan yang memadai; (4) adanya kepekaan terhadap dampak kemasyarakatan dari pekerjaan yang dilaksanakannya; (5) memungkinkan perkembangan sejalan dengan dinamika kehidupan.

Jarvis dalam buku Martinis Yamin mengatakan Profesi mempunyai pengertian seseorang yang melakukan tugas profesi juga sebagai seorang yang ahli atau mempunyai pengertian seseorang yang menekuni pekerjaan berdasarkan keahlian, kemampuan, teknik dan prosedur berlandaskan intelektualitas. ${ }^{28}$ profesionalitas guru sangat penting karena guru sebagai sosok dengan tanggung jawab mentransfer pengetahuan kepada peserta didik, dan juga menjadi contoh dan tauladan bagi peserta didik lainnya. Sehingga dengan demikian, apabila seorang guru memiliki integritas keilmuan yang tinggi, maka secara otomatis akan memberikan motivasi tersendiri bagi peserta didik untuk mengembangkan ilmunya yang ditekuni oleh guru tersebut. Namun sebaliknya, apabila seorang guru tidak memperhatikan betapa pentingnya ilmu, dan variasi atau metode dalam mengajar maka peserta didik akan merasa jenu dan bosan dalam belajar di madrasah.

Secara konseptual profesional guru mencakup tiga aspek yaitu: (a) Kemampuan profesional (b) Kemampuan sosial dan (c) Kemampuan personal (pribadi). Kemudian ketiga aspek itu dijabarkan menjadi: a. Kemampuan profesional mencakup: 1) Penguasaan materi pelajaran yang terdiri atas penguasaan bahan yang harus dijabarkan dan nkonsep-konsep dasar keilmuan dari bahan yang diajarkannya itu 2) Penguasaan dan penghayatan atas landasan dan wawasan kependidikan dan keguruan 3) penguasaan proses - proses kependidikan, keguruan dan pembelajaran siswa. b. Kemampuan sosial mencakup kemampuan untuk menyesuaikan diri kepada tuntutan kerja dan lingkungan sekitar pada waktu membawa tugasnya sebagai guru. c. Kemampuan personal (pribadi) mencakup 1) Penampilan sikap yang positif terhadap keseluruhan tugasnya sebagai guru 2) Pemahaman, penghayatan, dan penampilan nilai-nilai sebagai seorang guru.3) Penampilannya sebagai panutan dan teladan bagi para siswanya.

Menurut H. Douglas Brown seorang guru adalah "We will call the first set of principles cognitive because they relate mainly to mental and intellectual functions. it should be made clear however that all twelve of the principle outlined in this

27 Hamzah B Uno dan Masri Kuadrat, Megelola Kecerdasan dalam pembelajaran ( Jakarta: Bumi Aksara, 2009) hlm. 25.

${ }^{28}$ Martinis yamin, Sertifikasi profesi keguruan di Indonesia ( Jakarta : GP Press group, 2013) hlm. 20 . 
chapter spill across somewhat arbitrary cognitive, affective and linguistic boundaries."29 Seorang guru mampu mengembang sikap Kognitif ( pengetahuan), Afektif ( sikap) dan psikomotorik ( keterampilan).

Menurut Saiful sagala keberhasilan guru melaksanakan kegiatan pembelajaran tidak saja menuntut kemampuan menguasai materi pelajaran, strategi dan metode mengajar, menggunakan media atau alat pembelajaran. Tetapi guru dituntut tugas profesionalnya dalam menyediakan atau menciptakan situasi dan kondisi belajar yang kondusif dan menyenangkan yang memungkinkan kegiatan belajar mengajar bisa berjalan dengan baik sesuai perencanaan dan mencapai tujuan sesuai yang dikehendaki. ${ }^{30}$ Guru adalah salah satu komponen yang terpenting dalam lembaga pendidikan. Pendidikan Nasional sebagai suatu sistem mempunyai ciri-ciri sebagai berikut: (1) mempuyai komponen yang saling berhubungan satu sama lain, (2) komponen tersebut merupakan satu kesatuan, (3) mempunyai tujuan tertentu, (4) tujuan itu dapat di capai dengan berfungsinya komponen tersebut. ${ }^{31}$

Menuntut ilmu merupakan kewajiban dan kebutuhan manusia,Tanpa menuntut ilmu manusia akan tersesat dari jalan kebenaran. Tanpa menuntut ilmu manusia tidak akan mampu merubah suatu peradaban. Bahkan dirinyapun tidak bisa menjadi lebih baik. Karena menuntut ilmu merupakan sesuatu yang sangat penting dan merupakan kewajiban bagi setiap muslim. Dari uraian tadi sudah menjadi keseharusan dalam mempelajari ilmu, dalam menuntut ilmu dibutuhkan bimbingan guru, maka dalam memberikan bimibingan dan pengajaran dibutuhkan guru yang profesional dengan guru yang profesional mutu pendidikan akan dapat terwujud, islam mengajarkan agar ada segolongan manusia yang mampu memberikan ilmu dan mendalami ilmu terutama ilmu agama.

Profesionalitas adalah pandangan bahwa suatu keahlian tertentu diperlukan dalam pekerjaan tertentu, dan keahlian itu hanya diperoleh melalui pendidikan khusus atau latihan khusus. Profesionalitas menekankan pada penguasaan ilmu pengetahuan atau kemampuan manajemen beserta strategi penerapannya. Profesionalitas bukan sekedar pengetahuan teknologi dan manajemen, melainkan lebih merupakan sikap, pengembangan profesionalitas bukan hanya memiliki keterampilan yang tinggi tetapi memiliki tingkah laku yang dipersyaratka. ${ }^{32}$ Profesi menunjukan lapangan yang khusus dan mensyaratkan studi dan penguasaan pengetahuan khusus yang mendalam. Pekerjaan yang bersifat profesioanal adalah pekerjaan yang hanya dapat dilakukan oleh mereka yang khusus dipersiapkan untuk itu dan bukan pekerjaan yang dilakukan oleh mereka karena tidak dapat memperoleh pekerjaan.

Adanya profesionalitas pada guru dapat memberikan pembelajaran yang berkualitas baik, sehingga menjadikan generasi yang berkualitas baik juga dan mampu mengikuti perkembangan zaman yang ada. Profesionalitas menggambarkan keadaan seseorang untuk selalu berpikir, berpendirian, bersikap dan bekerja dengan sungguh-sungguh, kerja keras, disiplin untuk keberhasilan

${ }^{29}$ H. Douglas Brown, Teaching by Principles An Interantive Approach to language pedagogy, (San Francisco, California, 2000), hlm. 55

${ }^{30}$ Syaiful sagala, Adminitrasi pendidikan kontemporer, ( Bandung: Alfabeta, 2008) hlm. 83.

${ }^{31}$ Suprijanto, Pendidikian orang dewasa, ( Jakarta: Sinar Grafika, 2007), hlm. 5

32 Aan Hasanah,Pengembangan Profesi Guru,(Bandung:Pustaka Setia, 20012),hlm. 17. 
pekerjaannya. Profesionalitas seseorang membutuhkan ketrampilan dan keahlian yang dimiliki sesuai dengan profesi yang digeluti.

Mc Cully mengatakan bahwa "profession is a vocation in which professed knowledge of some department of learning or science is used in its application to the affairs of other or in the practice of an art founded upon it." Profesi adalah sebuah pekerjaan di mana pengetahuan yang dimiliki (diyakini) dari bagian-bagian (proses) pembelajaran dan sains yang diterapkan ke dalam usaha-usaha praktis dari sebuah seni yang dijumpai atasnya atau yang lain.

Profesi guru memiliki tugas melayani masyarakat dalam bidang pendidikan. Tuntutan profesi ini memberikan layanan yang optimal dalam bidang pendidikan kepada masyarakat. Secara khusus guru dituntut untuk memberikan layanan professional kepada peserta didik agar tujuan pembelajaran tercapai. Sehingga guru yang dikatakan profesional adalah orang yang memeiliki kemampuan dan keahlian khusus dalam bidang keguruan sehingga ia mampu melaksanakan tugas dan fungsinya sebagai guru dengan kemampuan maksimal. Madrasah merupakan suatu wadah untuk menciptakan sosok manusia yang berpendidikan tanpa melihat latar belakang siswa yang terlibat di dalamnya, baik dari segi budaya, sosial, maupun ekonomi. Madrasah menjadi suatu organisasi yang dirancang untuk dapat memberikan kontribusi dalam upaya peningkatan kualitas hidup masyarakat luas. Tiada kata puas di dalam mengelola madrasah, inovasi bergulir terus, hari ini lebih baik dari hari kemarin, dan besok lebih baik dari hari ini. Para profesional pendidikan harus meramu kiat sukses dalam mengelola madrasah, terutama mencapai tujuan pendidikan, memecahkan masalah, memperbaiki proses dan mengembangkan madrasah, pendidikan, dan pembelajaran yang diperlukan. ${ }^{33}$.

Berdasarkan paparan di atas profesionalitas adalah sikap para anggota profesi terhadap profesinya serta pengetahuan dan keahlian yang dimilikinya dalam menjalankan tugas dan tanggung jawab sebagai guru secara profesional, dalam melaksanakan tugas profesinya memiliki standar dan kode etik yang telah diterapkan dalam pelaksanaan profesinya. Guru dikenal sebagai al-mu'alim atau alustadz dalam bahasa Arab yang bertugas untuk memberikan ilmu dalam majelis taklim. Guru adalah seseorang yang memberikan ilmu. Pendapat klasik mengatakan bahwa guru adalah orang yang pekerjaannya mengajar. Namun pada dinamika selanjutnya guru disebut sebagai pendidik profesional karena guru itu telah menerima dan memikul beban dari orang tua untuk ikut mendidik anak. ${ }^{34}$

Jabatan guru merupakan jabatan profesional, dan sebagai jabatan profesional, pemegangnya harus memenuhi kualifikasi tertentu. Kriteria jabatan profesional antara lain bahwa jabatan itu melibatkan kegiatan intelektual, mempunyai batang tubuh ilmu yang khusus, memerlukan persiapan lama untuk memangkunya, memerlukan latihan dalam jabatan yang bersinambungan, merupakan karier hidup dan keanggotaan yang permanen, mementingkan layanan, mempunyai organisasi profesional, dan mempunyai kode etik yang ditaati

${ }^{33}$ Martinis Yamin dan Maisah, Standarisasi Kinerja Guru, (Jakarta : Gaung Persada, 2010), h.33.

34 Jamil Suprihatiningrum, Guru Profesional Pedoman Kinerja, Kualifikasi dan Kompetensi Guru (Yogyakarta: Ar-ruzz Media, 2013), hlm.. 23 
oleh anggotanya. ${ }^{35}$ Guru sebagai pendidik profesional mempunyai citra yang baik di masyarakat apabila dapat menunjukkan pada masyarakat bahwa ia layak menjadi panutan atau teladan masyarakat sekelilingnya. Masyarakat terutama akan melihat bagaimana sikap dan perbuatan guru itu sehari-hari, apakah patut diteladani atau tidak.

Seorang guru harus mampu berinovasi. Menurut P. Ely dalam Udin "an Innovation ia an idea for accomplishing some recognition social and in a new way for a means of accomlishing some social". Sedangkan menurut Huberman dalam Udin "Innovation is...... the creative selection, organization and uttilization of human and material resorces in new and unique ways wich will result in the attainment of a higher level of achievement for the defined goals and objectives" 36 . Adapun indikatornya adalah mampu: 1) konsistensi, 2) tanggung jawab, 3) keterbukaan, 4) orientasi $\mathrm{R} / \mathrm{P}, 5$ ) kreativitas

\section{Pengaruh Kepemimpinan dan Disiplin terhadap Profesionalitas Guru di MTs Negeri Kota Jambi}

Berdasarkan hasil penelitian dengan angka ideal adalah 100\%, rata-rata skor variabel profesionalitas guru 104,91 atau 67,7\% angka tersebut menggambarkan bahwa rata-rata profesionalitas guru sudah mencapai 61,7\%. Profesionalitas guru sudah berada pada katagori baik, tetapi belum mencapai tingkat kesempurnaan, masih perlu perbaikan dan komunikasi antara variabel agar saling mendukung untuk memajukan profesinalitas guru. Variabel Kepemimpinan kepala madrasah 101,45 atau $63,4 \%$, bersadarkan nilai rata - rata tersebut Kepemimpinan kepala Madrasah sudah berjalan sangat baik, walaupun belum mencapai kesempurnaan. Skor rata-rata disiplin guru adalah 104,79 atau 63.5\% berada pada katagori sangat baik. Hasil penelitian ini sejalan dengan kajian teoritik, bahwa terciptanya profesionalitas guru melalui proses yang panjang dan secara bertahap dan berkelanjutan dengan tahapan pertama adalah dibawa oleh pendiri ${ }^{37}$. Profesionalitas guru terbentuk atas peran guru sebagai fasilitator.

Apabila dicermati dari hasil analisis jalur antara variabel Kepemimpinan kepala Madrasah $\left(\mathrm{X}_{1}\right)$ dan disiplin guru $\left(\mathrm{X}_{2}\right)$ dengan variabel profesioalitas guru $\left(\mathrm{X}_{3}\right)$, maka terbentuk pengaruh positif dan signifikan. Artinya adalah semakin baik Kepemimpinan kepala Madrasah dan disiplin guru maka akan berpengaruh baik juga terhadap profesionalitas guru. Demikian juga dengan pengaruh disiplin guru dengan profesionalitas guru artinya semakin baik disiplin guru maka berpengaruh baik juga terhadap profesionalitas guru

Mengetahui koefisien jalur antara yang menyatakan persentase besarnya pengaruh langsung maupun tidak langsung dari variabel eksogen dan variabel endogen, berupa hubungan kausal atau hubungan satu arah, dapat dilihat berapa besar persentase pengaruh Kepemimpinan kepala Madrasah mempengaruhi profesionalitas guru. Adapun hasil perhitungan untuk koefisien jalur antara Kepemimpinan kepala Madrasah terhadap profesionalitas guru sebesar $=0.8372$,

35 Soetjipto dan Raflis Kosasi, Profesi Keguruan, (Jakarta: Rineka Cipta, 2009), hlm.. 37.

36 Udin Syaefudin Sa'ud, Inovasi Pendidikan (Bandung: Alfabeta, 2013), hlm.. .3-4.

37 Matondang, Kepemimpinan, Budaya Organisasi dan Manajemen Strategik, (Yogyakarta: Graha Ilmu, 2008), hlm..47. 
hal ini berarti 83,72\% profesionalitas guru yang terbentuk dipengaruhi oleh Kepemimpinan kepala Madrasah dan sisanya 16,28\% dipengaruhi oleh variabel lain diluar jalur yang diteliti.

Hasil penelitian ini sejalan dengan pendapat John M. Ivancevich, The experience and leadership style of the operating manager or leader directly effect human resource manajement activities because many, if not most, programs must be implemented at the work-unit level ${ }^{38}$ dan teori yang dikemukakan oleh Greiner yang dikutif oleh Syamsir Torang yaitu organisasi-organisasi yang melakukan perubahan kearah lebih baik adalah organisasi yang para pemimpinnya melibatkan bawahan dalam penerapan gagasan-gagasan baru ${ }^{39}$. Teori ini memberikan kejelasan bahwa perubahan untuk arah lebih baik, dalam hal ini perubahan profesionalitas guru dipengaruhi oleh Kepemimpinan kepala Madrasah yang mampu membimbing bawahannya, yaitu karektristik dari disiplin guru yang baik.

Koefisien jalur antara disiplin guru terhadap profesionalitas guru sebesar = 0.2215 , hal ini berarti 22,15\% profesionalitas guru dipengaruhi oleh disiplin guru, selebihnya $77,82 \%$ dipengraruhi oleh variabel lain diluar variabel yang diteliti, hal ini sejalan tengan teori bahwa proses terbentuknya profesionalitas guru membutuhkan proses yang melibatkan guru-guru yang memiliki komitmen dan kompotensi yang baik, yaitu orang-orang yang dianggap berpengaruh atau kharismatik. Orang-orang yang dianggap berpengaruh disini adalah para guru yang professional dalam menjalankan fungsi sebagai tenaga fungsional dan juga mendapat pengakuan oleh orang-orang yang dipimpinnya sehingga memenuhi syarat sebagai seorang guru yang profesional. Koefisien jalur Kepemimpinan kepala Madrasah terhadap disiplin guru adalah sebesar $=0,292$ hal ini berarti disipilin guru 29,2\% dipengaruhi oleh Kepemimpinan kepala Madrasah, hal tersebut sejalan dengan pernyataan bahwa peningkatan profesionalitas guru adalah kata kunci kesuksesan seorang guru. Oleh sebab itu, sangat penting, bahkan menjadi keharusan bagi guru untuk melibatkan siswa dalam proses perencanaan, pengorganisasian, pelaksanaan, pemantauan, evaluasi, dan perbaikan terusmenerus. ${ }^{40}$

Besarnya pengaruh simultan antara variabel Kepemimpinan kepala Madrasah dan disiplin guru terhadap profesionalitas guru dinyatakan oleh besarnya nilai $R_{\text {square }}\left(R^{2}\right)$. Hasil perhitungan nilai $R_{\text {square }}\left(R^{2}\right)$ adalah $=0.172$ hal ini berari 17,2\% profesionalitas guru dipengaruhi oleh variabel Kepemimpinan kepala Madrasah dan disiplin secara simultan. Hasil penelitian ini sejalan dengan pendapat bahwa gambaran sekolah masa depan yang berorintasi pada karekteristik siswa yang memiliki keahlian, kefasihan, pemahaman dan jiwa multikultural dan mempunyai kinerja yang berstandar excellent tersebut

${ }^{38}$ John m. Ivancevich, Human Resource Manajement, Twelfth Edition, (Buston: McGraw-Hill, 2011), hlm.. 46.

39 Syamsir Torang, Oeganisasi Manajemen ( Perilaku, Struktur, Buday \& Perubahan Organisasi) , ( Bandung: Alfabeta, 20130, hlm. 122.

40 Jamal Ma'mur Asmani, Tips Menjadi Kepala Sekolah Profesional, ( Yogyakarta: Diva Press, 2012), hlm. 234. 
membutuhkan pemimpin yang mempunyai kapabilitas tinggi, sehingga mampu mengerakan roda organisasi akseleratif.

Hal yang menarik untuk dicermati adalah besarnya pengaruh antar variabel penelitian. Berdasarkan besarnya koefisien jalur $(\rho)$ yang diperoleh antara variabel Kepemimpinan kepala Madrasah terhadap profesionalitas guru sebesar 0.823, maka keeratan pengaruh dua variabel ini adalah pada tingkat keeratan sangat tinggi. Besarnya koefisien jalur $(\rho)$ yang diperoleh antara variabel disiplin guru dengan profesionalitas guru sebesar 0.248 maka keeratan pengaruh kedua variabel ini adalah pada tingkatan sangat rendah. Besarnya koefisien jalur $(\rho)$ variable kepemimpinan kepala madrasah dengan disiplin guru adalah sebesar 0.540, maka keeratan pengaruh dua variabel ini pada tingkatan tinggi. Koefisien determinasi antara variabel Kepemimpinan kepala Madrasah dan disiplin guru terhadap profesionalitas guru sebesar 0.828 , jadi keeratan antara variabel tersebut berada pada tingkatan sangat tinggi. Kecenderungan yang ditemukan pada penelitian ini masing-masing variable penelitian secara sendiri-sendiri dalam membangun profesionalitas guru berpengaruh lebih rendah jika dibandingkan dengan faktor Kepemimpinan kepala Madrasah dan disiplin guru, bila kedua variabel eksogen tersebut bekerja secara bersama-sama terhadap variabel endogen.

Dalam penelitian ini profesionalitas guru dilihat dari keterlibatan semua warga sekolah yang mencakup keterlibatan pada pola, Kepemimpinan kepala Madrasah. Konsistesi semua warga organisasi pada pola komunikasi, saling menghormati dan juga konsisten terhadap penampilan fisik sekolah adalah dimensi kedua dalam mengukur profesionalitas. Dalam pengukuran profesinalitas adalah adaptabilitas, yang indikatornya berupa antisipasi terhadap perubahan, selalu berorientasi terhadap hasil, membentuk tim kerja dan kompetitif. Serta dimensi keempat berupa misi sekolah yang antara lain berupa peningkatan kinerja kepala sekolah dan guru, siswa yang berprestasi dan guru yang unggul. Keempat dimensi tersebut, secara bersinerji diharapkan dapat membangun profesionalitas guru yang baik. Berkenaan dengan disiplin guru, menurut Martinis, disiplin dalam perilaku berarti tunduk atau patuh terhadap peraturan. ${ }^{41}$ Menurut Gie dalam Wukir disiplin dalam akademik berarti suatu cabang studi atau subyek yang khusus digunakan dalam tingkatan organisasi ${ }^{42}$.

\section{Penutup}

Berdasarkan hasil perhitungan statistik dan analisis data yang telah diuraikan pada bab sebelumnya, maka temuan dari hasil penelitian ini dapat diambil kesimpulan bahwa terdapat pengaruh positif dan signifikan antara Kepemimpinan kepala madrasah $\left(\mathrm{X}_{1}\right)$ terhadap profesionalitas guru $\left(\mathrm{X}_{3}\right)$, artinya semakin baik Kepemimpinan kepala madrasah maka berpengaruh terhadap profesionalitas guru. Besarnya pengaruh Kepemimpinan kepala Madrasah ( $\left.\mathrm{X}_{1}\right)$ terhadap Profesionalitas guru $\left(\mathrm{X}_{3}\right)$ adalah $83,72 \%$. Terdapat pengaruh positif dan signifikan antara disiplin guru $\left(\mathrm{X}_{2}\right)$ terhadap profesionalitas guru $\left(\mathrm{X}_{3}\right)$, artinya semakin baik

41 Martinis Yamin, Paradigma Baru Pembelajaran, (Ciputat: Mega Mall, 2013), hlm.. 93

${ }^{42}$ H. Wukir, Manajemen Sumber Daya Manusia dalam Organisasi Sekolah, (Yogyakarta: Multi Presindo, 2013), hlm.. 92 
disiplin guru maka semakin tinggi profesionalitas guru. Besarnya pengaruh Disiplin Guru $\left(\mathrm{X}_{2}\right)$ terhadapProfesionalitas Guru $\left(\mathrm{X}_{3}\right)$ adalah 22,15\%. Terdapat pengaruh positif dan signifikan antara kepemimpinan kepala madrasah $\left(\mathrm{X}_{1}\right)$ terhadap disiplin guru $\left(\mathrm{X}_{2}\right)$, artinya semakin baik kepemimpinan kepala madrasah maka kedisiplinan guru semangkin meningkat.besarnya pengaruh kepemimpinan Kepala Madrasah $\left(\mathrm{X}_{1}\right)$ terhadap Disiplin Guru $\left(\mathrm{X}_{2}\right)$ adalah 54. Secara keseluruhan ada terdapat pengaruh positif dan signifikan secara simultan antara Kepemimpinan kepala madrasah $\left(\mathrm{X}_{1}\right)$ dan disiplin guru $\left(\mathrm{X}_{2}\right)$ terhadap profesionalitas guru $\left(\mathrm{X}_{3}\right)$. Hasil penelitian ini menginformasikan bahwa semakin baik Kepemimpinan kepala madrasah yang disertai disiplin seorang guru maka akan berpengaruh terhadap terbentuknya profesionalitas guru yang semakin baik.besarnya pengaruh Kepemimpinan kepala madrasah $\left(\mathrm{X}_{1}\right)$ dan disiplin guru $\left(\mathrm{X}_{2}\right)$ terhadap profesionalitas guru $\left(\mathrm{X}_{3}\right)$ adalah $17,2 \%$.[]

\section{Bibliografi}

Aan Hasanah,Pengembangan Profesi Guru, Bandung: Pustaka Setia, 2012.

Buchari, Alma Guru Profesional, Bandung: Alfabetha, 2009.

Dedi Mulyasana, Pendidikan bermutu dan berdaya saing, Bandung: PT Remaja Rosdakarya, 2012.

Departemen Agama, Al-Qur'an dan terjemahannya, Jakarta: Departemen Agama RI, 1989.

Douglas Brown, Teaching by Principles An Interantive Approach to language pedagogy, San Francisco, California, 2000.

E. Mulyasa. Menjadi Kepala Sekolah Profesional, Bandung: PT. Remaja Rosda Karya, 2009.

E. Mulyasa, Menjadi Guru Profesional, Bandung: PT Remaja Rosda Karya, 2010.

Edy Sutrisno, Manajemen Sumber Daya Manusia, Kencana Predana Media Group, 2009.

Euis Karyawati dan Donni Juni Priansa, Kinerja dan Profesionalisme Kepala Sekolah Membangun Sekolah yang Bermutu, Bandung: Alfabeta, 2013.

Fachruddin Saudagar, Ali Idrus, Pengembangan Profesionalitas Guru, Jakarta: Gaung Persada, 2009.

Fred Luthans dan Jonathan P. Doh, International Management CulturStrategy and Behavior, New York: Mc. Graw Hill : 2006.

Gary Yuky, Leadership in Organization, New Jersey: Prentice Hall Inc., 2010.

H. Wukir, Manajemen Sumber Daya Manusia dalam Organisasi Sekolah, Yogyakarta: Multi Presindo, 2013.

Hamzah B Uno dan Masri Kuadrat, Megelola Kecerdasan dalam pembelajaran, Jakarta: Bumi Aksara, 2009.

Jamal Ma'mur Asmani, Tips Menjadi Kepala Sekolah Profesional, Yogyakarta: Diva Press, 2012.

Jamil Suprihatiningrum, Guru Profesional Pedoman Kinerja, Kualifikasi dan Kompetensi Guru ,Yogyakarta: Ar-ruzz Media, 2013. 
John m. Ivancevich, Human Resource Management, Twelfth Edition, Boston: McGraw-Hill, 2011.

John R. Schermerhon, JR., Introduction to Management, Hoboken: John. Wiley \& Sons (Asia) Pte Ltd, 2010.

Kennth Randrews, Toward Profesionalism in Bussinnes Management Harvard, Busisnnes Review, Marc-April 1969.

Kim Marshall, Rethinking Teacher Supervision and Evaluation, Amerika : John Wiley \& Sons, Inc, 2009

Kunandar, Guru Profesional Implementasi Kurikulum Tingkat satuan Pendidikan (KTSP) dan Presiapan Menghadapi Sertifikasi Guru Jakarta: Raja Grafindo Persada,2007.

Martinis Yamin, Paradigma Baru Pembelajaran, (Ciputat: Mega Mall, 2013)

Martinis Yamin dan Maisah, Standarisasi Kinerja Guru, (Jakarta : Gaung Persada, 2010.

Martinis yamin, Sertifikasi profesi keguruan di Indonesia, (Jakarta: GP Press group, 2013).

Matondang, Kepemimpinan, Budaya Organisasi dan Manajemen Strategik, Yogyakarta: Graha Ilmu, 2008.

Muhaimin, Sutiah dan Sugeng listyo prabowo, Pengembangan Model KTSP pada sekolah dan madrasah, Jakarta: Raja Grafindo Persada, 2008

Mukhtar dan Iskandar, Orientasi baru Supervisi pendidikan, Jakarta: Gaung Persada, 2009.

Nanang Fattah, Landasan Manajemen Pendidikan, Bandung: PT. Remaja Rosdakarya, 2009.

Pupuh Fathurrohman, Guru Profesional, Bandung: PT Refika Aditama, 2012.

Robert Kreitner dan Angelo Kinicki, Organizational Behavior, (Amerika : Mc. Graw Hill Companies, 2007)

Rohmat, Kepemimpinan Pendidikan Konsep dan Aplikasi (Purwokerto: STAIN Press, 2010)

Sudarman Danim dan Khairil, Profesi Kependidikan,( Bandung: alfabeta, 2011)

Sukardi, Metodologi Penelitian Pendidikan Kompetensi dan Praktiknya, (Jakarta:Bumi Aksara,2013)

Suprijanto, Pendidikian orang dewasa, ( Jakarta: Sinar Grafika, 2007), hal 5

Sutarto, Dasar-dasar Kepemimpinan Administrasi, (Yogyakarta: Gadjah Mada University Press, 1989)

Soetjipto dan Raflis Kosasi, Profesi Keguruan, (Jakarta: Rineka Cipta, 2009)

Syaiful Sagala, Adminitrasi Pendidikan Kontemporer, (Bandung: Alfabeta, 2008) Syamsir Torang, Oeganisasi Manajemen ( Perilaku, Struktur, Buday \& Perubahan Organisasi) , ( Bandung: Alfabeta, 20130)

Tim Dosen Administrasi Pendidikan Universitas Indonesia, Manajemen pendidikan (Bandung : Apabeta,200)

Udin Syaefudin Sa'ud, Inovasi Pendidikan (Bandung: Alfabeta, 2013).

William B. Castetter, The Personnel Function in Educational Administration, (New York Macmillan Publishing Co., Inc., tt) 